\title{
Restructuring of the Cameroon Development Corporation, Challenges and Coping Strategies of Plantation Workers in Fako Division, South West Region, Cameroon
}

\author{
Clovis Ebot Obale* \\ Ph.D candidate, Department of Geography University of Yaounde I, Yaounde-Cameroon, Faculty of Arts, \\ letters and Social Sciences, Cameroon
}

*Corresponding Author: Clovis Ebot Obale, Ph.D candidate, Department of Geography University of Yaounde I, Yaounde-Cameroon, Faculty of Arts, letters and Social Sciences, Cameroon

\begin{abstract}
Industrial restructuring that took place in most developing countries after the mid-1980s failed to take into consideration the working and living conditions of workers, since multinational companies that bought over state owned enterprises focused more on profit maximization at the detriment of workers welfare. This study explores the challenges and coping strategies of workers of the Cameroon Development Corporation $(C D C)$ in the context of neoliberal restructuring masterminded by the Bretton Wood Institutions. The researcher employed a qualitative phenomenological research design with purposeful sampling of participants. Data collection entailed conducting in-depth interviews and focus group discussions with 120 male and female workers drawn from four CDC camps in Fako Division. The study affirms that the restructuring of the CDC had negative consequences on the living and working conditions of workers. In a bid to salvage the situation workers had to reduce their expenditure and diversify their sources of income. The coping strategies that were employed by workers to curb the negative effects of these restructuring failed to ameliorate their living conditions, though little has been done by the CDC, CTE and Delmonte to ameliorate their situation, despite huge sacrifices they have made to restore the CDC to its past glory.
\end{abstract}

Keywords: Industrial restructuring, Neoliberal restructuring, Cameroon Development Corporation, Bretton Wood Institutions, Coping strategies, Cameroon Tea Estate, Delmonte, Plantation workers and Fako Division

Abbreviations: CDC-Cameroon Development Corporation, XAF-Central African CFA franc, CTECameroon Tea Estates FCFA Franc- Central African CFA franc, HHs-Households, IMF-International Monetary Fund, PEs-Public Enterprises, SOEs-State Owned Enterprises

\section{INTRODUCTION}

Public or state owned enterprises occupy an important position in the economy of most countries of the developing world, despite their political orientation. They play an important role in promoting social and economic development in Cameroon. The world economic crisis of 1986 which affected Cameroon forced her to implement without success a series of internal austerity measures in a bid to ameliorate the macro-economic situation of the country (Konings, 1996c). In the face of this dwindling economic situation the government was forced to seek financial assistance from the IMF and World Bank, who provided loans with laid down conditionality's culminating to a series of neoliberal economic reforms in public and para-public enterprises (Konings, 1995).The neoliberal restructuring of the CDC in the mid-1980s and early 1990s failed to take into consideration the working and living conditions of workers, since multinational companies that bought over these state owned enterprise focused more on profit maximization at the detriment of the welfare of plantation workers. The restructuring of the CDC have had negative consequences on the living and working conditions of the workers. The coping strategies that were employed by these workers to curb the negative effects of this neoliberal restructuring of the CDC has been ineffective, thereby rendering the workers poor and miserable (Konings, 1996c).Despite the growing importance of plantation workers in the economy of most Sub-Saharan African countries, documented research on livelihood and coping strategies focus more on food security of rural households than those of plantation workers (Christiansen, 2004).The results of this study might provide useful insights for policy makers on how 
Restructuring of the Cameroon Development Corporation, Challenges and Coping Strategies of Plantation Workers in Fako Division, South West Region, Cameroon

to alleviate people in rural areas from poverty particularly those of agro-industries with very low minimum wage and poor working conditions.

\section{OBJECTIVES OF THE STUDY}

The main objective of this study is to make an assessment of the challenges that plantation workers faced during the neoliberal restructuring of the CDC and also to evaluate the coping strategies that were employed by workers to curb the negative effects of this restructuring.

\section{REVIEW OF RELATED LITERATURE}

Nzomo et al, (2007) affirms that state owned enterprises (SOEs) also known as parastatal in Cameroon were established to solve problems of market failure, promote economic development and reduce mass unemployment with the view to ensure control over the economy. Konings (1996c) also holds that the CDC was privatised in July 1995 amid discontent from the elites in the South West and North West Regions. The privatisation of the CDC was viewed by many Anglophone scholars as the height of the marginalisation of Anglophones by their Francophone counterpart. However, although the privatisation of the CDC was viewed as a sign of relief by the government and CDC management it further created other problems. The CTE and Delmonte immediately after privatisation decided to layoff unproductive workers without notice, increase working hours, and reduce all fringe benefits accorded to workers. World Bank (2018) also argues that countries that pursued privatization within a strategic policy framework for investment gained more from privatization compared to countries that approached it haphazardly like the case in Cameroon, Ivory Coast and Nigeria.

Households are subject to two types of shocks which are covariate shocks that affect the entire community and idiosyncratic shocks that affect particular households. They use varied risk-coping strategies to curb the negative effects of a shock. Households affected by shocks usually opt for low risk activities and asset portfolios culminating to low revenue. However, a better understanding of shocks and coping mechanisms of rural households may provide useful insights in designing poverty reduction policies that might help alleviate poverty in rural communities (Skoufias, 2005).Empirical studies on household coping strategies in SSA affirm that households first employ coping mechanisms with short-term effects such as spending savings and selling assets in case of a covariate shock. However, in a situation where these coping strategies are unsuccessful households may resort to long term strategies such as withdrawing children from school (Cameron, 2001).A review of the Cameroon household survey of 2007 assert that the most common coping strategies of poor households in rural areas of the country are spending available savings, selling assets, working longer hours, reducing food consumption and receiving help from family members and friends (NIS, 2008a).

\section{RESEARCH HYPOTHESIS}

$\mathrm{H}_{\mathrm{a}}$ : The restructuring of the CDC have had negative consequences on the livelihood of plantation workers.

$\mathrm{H}_{\mathrm{a}}$ : Coping strategies employed by plantation workers of the CDC to curb the negative effects of the restructuring on their livelihood have been ineffective.

\section{MATERIALS AND MeTHODS}

\subsection{Study Area}

The Cameroon Development Corporation is located in Fako Division in the South West Region of Cameroon, between latitudes $4^{\circ} 4^{\prime \prime}$ and $402^{\prime \prime}$ north of the Equator and longitudes $8^{\circ} 7^{\prime \prime}$ and $9^{\circ} 25^{\prime \prime}$ east of the Greenwich meridian. It is bounded on the west and south by the Biafra, in the east by the Wouri and Mungo Divisions of the Littoral Regions and on the North by Meme and Ndian Divisions (see Map 5.1).Fako Division covers an area of about 2.057 kilometres square with an estimated population of approximately 446,170. The headquarters of Fako-Division is found in Limbe. Agriculture is the major economic activity of the people, employing a large proportion of the population, with tomatoes, plantain, maize, cassava, and cocoyam as the main food crops. The CDC operates nine rubber estates, six oil palm Estates, five rubber factories and two palm oil mills in Mondoni and Lobe in the South West Region. These estates are found in the following localities in Fako-Division such as; Tiko, Likomba, Idenau, Bota, Meanja and Ekona (Fongod et al, 2013). 
Restructuring of the Cameroon Development Corporation, Challenges and Coping Strategies of Plantation Workers in Fako Division, South West Region, Cameroon

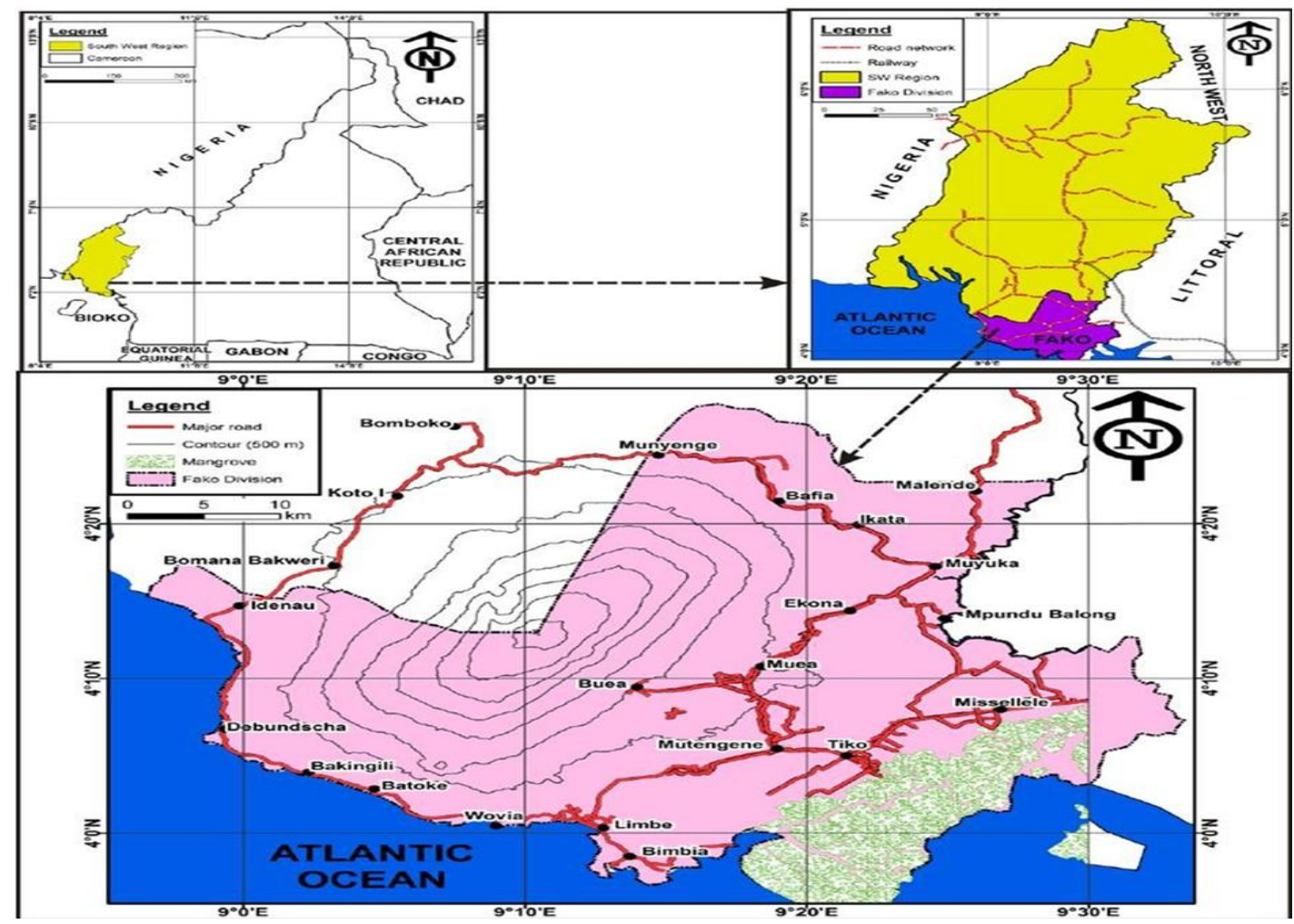

Map 5.1: Map of Fako Division

Source: (Fongod et al, 2015)

Map 5.1 clearly shows the different sub-divisions that make up Fako-Division.

\subsection{Methods and Techniques}

\subsubsection{Data Collection}

The research design of this study consists of a qualitative phenomenological research design with purposeful sampling of participants. The phenomenological approach tries to identify how phenomena are perceived by actors in a given context. In the human sphere this entails the gathering of in depth information and perceptions through inductive qualitative methods involving interviews, discussions and participant observation (Moustakas, 1994).Data collection entailed conducting in-depth interviews with 120 male and female workers drawn from four CDC camps in Fako Division. The fieldwork to collect data took place in February-April, 2016 during the first field visit and later in October-November, 2016 during the second field visit. Although it was highly demanding due to time constraints, it was the most preferred method due to its flexibility in eliciting detailed information from respondents in their own words, about their social world (Lofland and Lofland, 2006). The researcher also organised 4 focus group discussions with 32 workers that took place in four CDC camps (Tiko, Mondoni, Likomba and Tole) in March, 2016 with workers who have spent more than ten years in service. It was made up of 32 workers (16 male and 16 female) who were willing to take part in the focus group discussions. The researcher also made use of secondary material such as articles, published books, thesis and technical reports.

\subsubsection{Sampling Techniques of the Population}

Purposive sampling was employed to guide in the selection of four CDC estates to be used in the study, such as the Mondoni oil palm estate, Tole tea estate, Tiko- Delmonte banana estate, and Likomba rubber estate (see Map 5.2)(Yin, 2003). The CDC operates on several plantations located in different parts of the South West, Littoral, West and North West Regions of the country. The Tiko banana estate was chosen because of its prominence in the production of banana and stands out as the highest employee in the sector (see Table 5.1), Tole tea estate was also selected because it is the only tea estate in the South West Region, the Mondoni palm estate stands out as the oldest palm plantation and factory in Fako Division and lastly Likomba rubber estate is close to Tiko and operates a processing plant noted for its negative environmental effects on the local landscape. 
Restructuring of the Cameroon Development Corporation, Challenges and Coping Strategies of Plantation Workers in Fako Division, South West Region, Cameroon

Table5.1. CDC Plantations in Fako Division in 1999/1990

\begin{tabular}{|l|l|l|l|}
\hline Crop type & Location & Cultivated area/ha & Labour Force \\
\hline Tea & Tole & 439 & 1639 \\
\hline Banana & Tiko & 723 & 1326 \\
\hline Palm & Mondoni & 5320 & 820 \\
\hline Rubber & Likomba & 2654 & 740 \\
\hline
\end{tabular}

Source: CDC annual report sheet (1990)

Table 5.1indicates that in 1990 the Tole tea estate was one of the estates of the CDC employing the highest number of labourers, although it had the smallest land area under cultivation asserting that tea cultivation is labour intensive. Tiko banana estate ranked second with a labour force of 1326 on a cultivated land surface of about 728 hectares. The palm and rubber sectors were those employing the least number of people in the $\mathrm{CDC}$ at the time although they both occupy a large expanse of land.

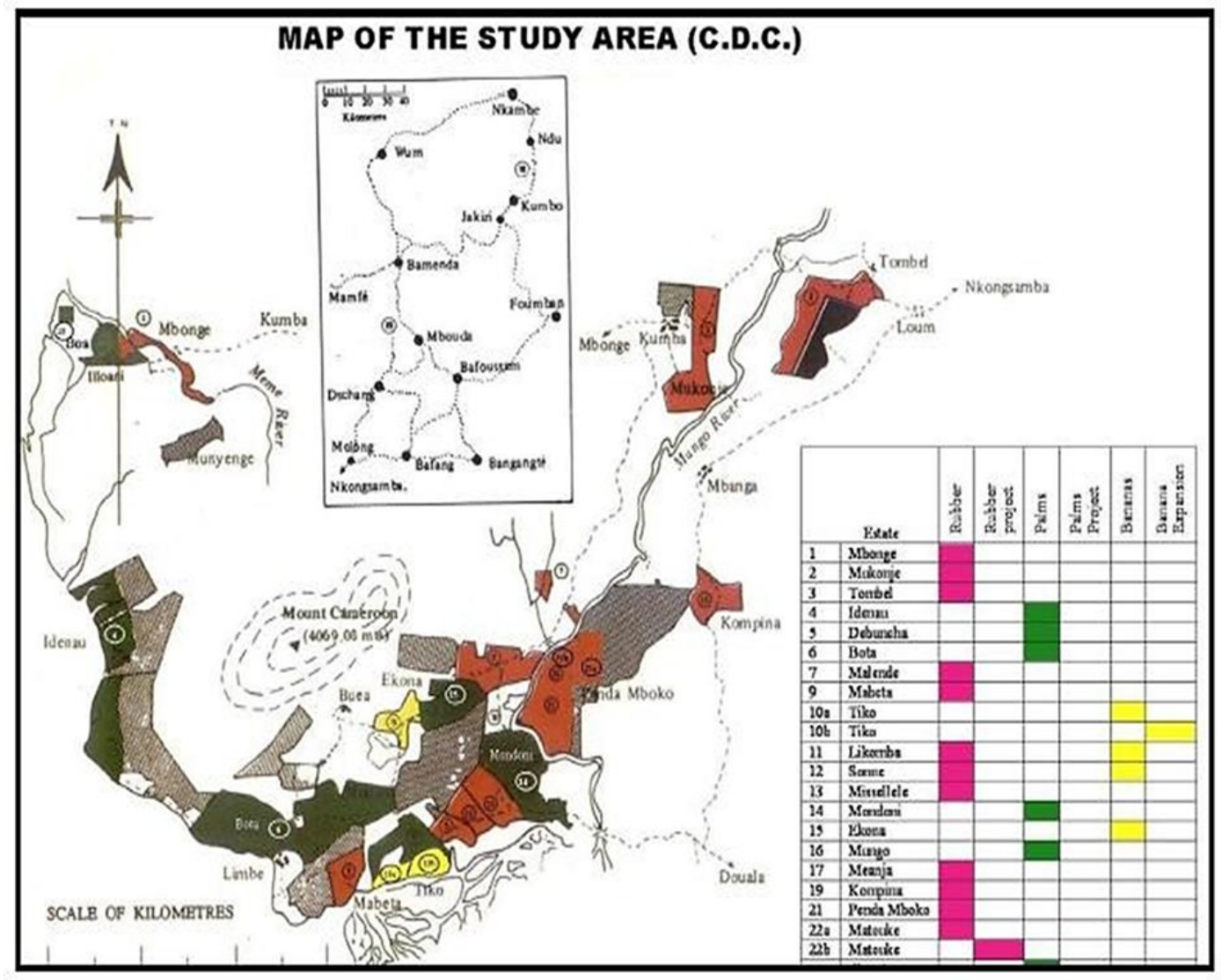

Map 5.2: Location of CDC Plantations

Source: (CDC annual report sheet, 2011)

Map 5.2.Clearly showcases the location of the four CDC estates selected for the study.

\subsubsection{Data Analysis}

The hermeneutical approach was used to interpret people's life experiences and meanings so as to develop an understanding of their world from an epistemological viewpoint, since knowledge is a social and subjective construct. The findings of the study were effectively rich accounts of people's realities, consisting of the factors shaping them and how they act within them and supplemented by descriptive statistical data analysis. Interpretation involved the collation of data into conclusions. Furthermore, data organization involved the continuous iterative display and assembling of data and information. This involved the production of descriptive data in the form of tables, graphs, networks and schematic diagrams. However, data and information were organized by putting them together into specific forms such as text. The parameters of some of the frameworks were used to guide this research inquiry, summarize data and information into an orderly manner during the data analysis and interpretation exercises. 
Restructuring of the Cameroon Development Corporation, Challenges and Coping Strategies of Plantation Workers in Fako Division, South West Region, Cameroon

\section{Results}

\subsection{Demographic Characteristics of Plantation Workers}

This study made use of 120 respondents distributed equally amongst the both sexes. The study asserts that more than $50 \%$ of those interviewed in the banana and tea estates are women owing to their dominance in these sectors (see Table 6.1).The study further affirms that $75 \%$ of the respondents are indigenes from the North West Region, while 23\% come from the South West Region and 2\% from the East and Western Regions Respectively.

Table6.1. Sex and region of origin of CDC workers

\begin{tabular}{|c|c|c|c|c|c|}
\hline Estate & \multicolumn{2}{|c|}{ Sex/Frequency } & \multicolumn{3}{|c|}{ Region of origin/Frequency } \\
\hline & Male & Female & NW & SW & other \\
\hline Banana & 10 & 20 & 25 & 05 & 00 \\
\hline Rubber & 20 & 10 & 25 & 03 & 02 \\
\hline Tea & 10 & 20 & 25 & 03 & 02 \\
\hline Palms & 20 & 10 & 20 & 05 & 05 \\
\hline Total & & & & & \\
\hline
\end{tabular}

Source: Field survey (2016)

Table 6.1 illustrates the sex and region of origin of the workers. The table asserts that more than $70 \%$ of CDC workers are natives from the North West Region.

The main reason for these disproportionate number of workers employed in the CDC owes much to history. The first reason to support this argument is that the Bakweri people who are indigenes of this area were considered by the Germans and later the British as very lazy people with little interest in plantation work. The North Westerners are hardworking people and come from a region with very few job opportunities. This therefore acted as a push factor for them to migrate to the coastal areas in search of greener pastures. More than $90 \%$ of the respondents have worked with the CDC for more than 10 years as permanent workers at the time of the interview with the majority ranging between 25 55 years of age (see Table 6.2 and 6.3).

Table6.2. Age and marital status of CDC workers

\begin{tabular}{|l|l|}
\hline Age & Per cent \\
\hline 15-25 years & 07.5 \\
\hline 25-35 years & 35.5 \\
\hline 35-45 years & 41.0 \\
\hline 45-55 years & 17.0 \\
\hline 55 years and older & 02.0 \\
\hline & $\mathbf{1 0 0}$ \\
\hline Marital status & \\
\hline Never married & 10 \\
\hline Married & 60 \\
\hline Widowed & 10 \\
\hline Divorced & 15 \\
\hline Free union & 05 \\
\hline & $\mathbf{1 0 0}$ \\
\hline
\end{tabular}

Source: Field survey (2016)

Table 6.2 presents the age and marital status of CDC workers.

More than $55 \%$ of the workers are married with children. It should also be noted that most of the workers are youths because of the strenuous nature of the job. It was also observed that the workers of the CDC live at close proximity to the plantations where they work to cut down travelling cost and time.. It should be noted that when the CDC was privatized several workers were laid off because of advanced age and inefficiency making it possible for those who were physically very strong and efficient to be retained. This therefore accounts for the reason why $90 \%$ of the workers fall between the 38-45 years age bracket. 
Restructuring of the Cameroon Development Corporation, Challenges and Coping Strategies of Plantation Workers in Fako Division, South West Region, Cameroon

Table6.3. Employment and Education

\begin{tabular}{|l|l|}
\hline Length of employment & Per cent \\
\hline $0-5$ & 17.0 \\
\hline $5-10$ years & 19.5 \\
\hline 10-15 years & 39.0 \\
\hline 15-25 years & 19.5 \\
\hline 25 years and above & 05.0 \\
\hline Total & $\mathbf{1 0 0}$ \\
\hline Education & 78.0 \\
\hline Illiterate & 20.5 \\
\hline Primary education & 01.5 \\
\hline Post-primary education & $\mathbf{1 0 0}$ \\
\hline Total &
\end{tabular}

Source: Field survey (2016)

Table 6.3 illustrates the duration of CDC labourers in service, level of education, their religion and number of children in each household

\section{SOCIO-ECONOMic Challenges FACED BY CDC WORKERS}

It is indeed ironic that despite large revenues generated by the CDC, there is a huge disparity in the economic status of CDC labourer's vis-à-vis CDC management. Despite being the backbone of the CDC, plantation workers have not been able to break out of the chain of poverty. The socio-economic challenges workers faces include poor salaries, poor living conditions, poor working conditions, demotivation and restricted career growth paths. The following sub-sections will present workers articulation of some of their main challenges.

\subsection{Low Salaries}

The CDC management and multinational companies who are shareholders give more preference to profit maximisation than to the welfare of workers. The study asserts that CDC women labourers are more exploited than men. In the Tole estate, more than $80 \%$ of female workers work in the field and were classified under general labour because their level of education is low. The study affirms that female field workers were placed on 118 FCFA an hour. Thus on a monthly basis these workers are on salaries ranging from 30,680 FCFA to 31, 186 FCFA. The CDC introduced also a compulsory saving scheme during the crisis period whereby workers were obliged to save FCFA 1,680 per month (Konings, 1993a). Figure 7.1 presents the average wage distribution for male and female workers. The study asserts that female workers earn less than 30.000 on average comparing to male workers who earn around 40.000 on average monthly.

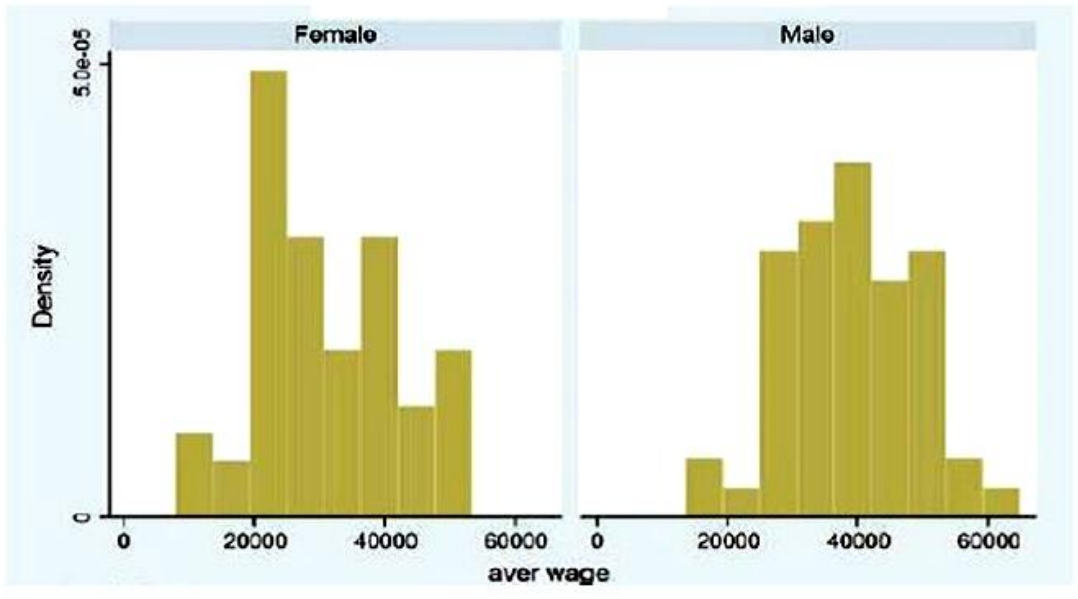

Figure7.1. Average wage by gender

Source: CDC annual report sheet (2014)

Figure 7.1illustrates the average wage by gender in the CDC.

International Journal of Research in Geography (IJRG) 


\subsection{Poor Living Conditions}

The living conditions of plantation workers in CDC camps is very deplorable from its inception particularly those of the Tole tea estate. The camp houses are plank structures that were poorly constructed thus exposing the workers to mosquitoes and other harmful environmental insects. The study reveals that more than $95 \%$ of the workers interviewed complained of rats and snakes that were invading residences. A cross section of the workers interviewed, also complained of congestion as a major problem. The average person per room is six and this could be explained by the fact that a man that is married to one wife or many wives was entitled only to one sitting room, a kitchen and a bedroom. This congestion was not only noted in the living rooms but equally in the toilet and bathroom facilities that were in these camps. The housesarealso poorly ventilated with leaking roofs due to poor maintenance. Plantation workers are given $25 \%$ of their wage, an equivalent of XAF5000, which does not cover the variable rent rates in the area of XAF7000- 10,000.

\subsection{Poor Working Conditions}

The working conditions for field workers in CDC plantations are deplorable. Despite their high input, what they reap is not commensurate to their labour. Workers in the field put in 8 hours a day, while harvesters and pack house workers tend to work for more than 10 hours a day...More than $90 \%$ of the workers assert that Sunday was the only day workers rest with their families. It was observed with a lot of dismay that several plantation workers in the palms and rubber sectors reported working on temporal contract for over 5 years before having a permanent contract. This explains why some workers with 8 and 9 years of service are currently in category 1A or 1B. The National Social Insurance covers workers between the hours of $6 \mathrm{am}$ and $6 \mathrm{pm}$. However, plantation workers often leave their homes at $4 \mathrm{am}$ and do not return until well past $6 \mathrm{pm}$. Workers involved in any form of accident during field operations go through a difficult procedure before they are paid their entitlements.

\subsection{Use of Agro-Chemicals}

Workers of the Tiko banana plantations have complained bitterly about the aerial spraying of chemicals in the farms. $80 \%$ of CDC workers stated that they are never informed about the day and place of spraying by management. CDC workers that find themselves in the field while the plane is spraying find it very difficult to run back to the pack house due to distance. However, there are many health problems associated with this chemical exposure, which are; skin rashes, irritation and eye damage. $50 \%$ of workers in the field and pack house clearly stated that when the chemical get into their eyes "it burns like pepper", and that even if they're not in the field during the spraying, they still get in touch with the chemical when touching the banana leafs or during harvesting. CDC camps built close to the plantation suffer from chemical drift and these spraying contaminate their water supply. Furthermore, the level of awareness of the dangers of handling and applying a range of fungicides, fertilizers, nematicides and pesticide amongst workers is very poor.

\subsection{Healthcare}

The CDC has constructed several hospitals and clinics to serve workers. Workers expressed a wide range of concerns about the healthcare provided by the CDC such as insufficient supplies of drugs. Workers often buy drugs and are not being reimbursed by the CDC. There exists a first aid post on each plantation which is poorly staffed. A healthcare contribution of 800 FCFA is being deducted from workers' wages monthly. In addition, $92 \%$ of the workers interviewed reported having body pains and $79 \%$ of them attributed these pains to the nature of the work they do at the plantation, which was considered tedious particularly for women. Malaria and typhoid were the second most reported health problems (63\%) due to the poor drinking water, dirty environment, poor waste disposal and dirty toilets very close to camp houses, followed by eye infections (43\%) and skin rashes (41\%) as a result of agrochemicals during spraying and manual application. 
Restructuring of the Cameroon Development Corporation, Challenges and Coping Strategies of Plantation Workers in Fako Division, South West Region, Cameroon

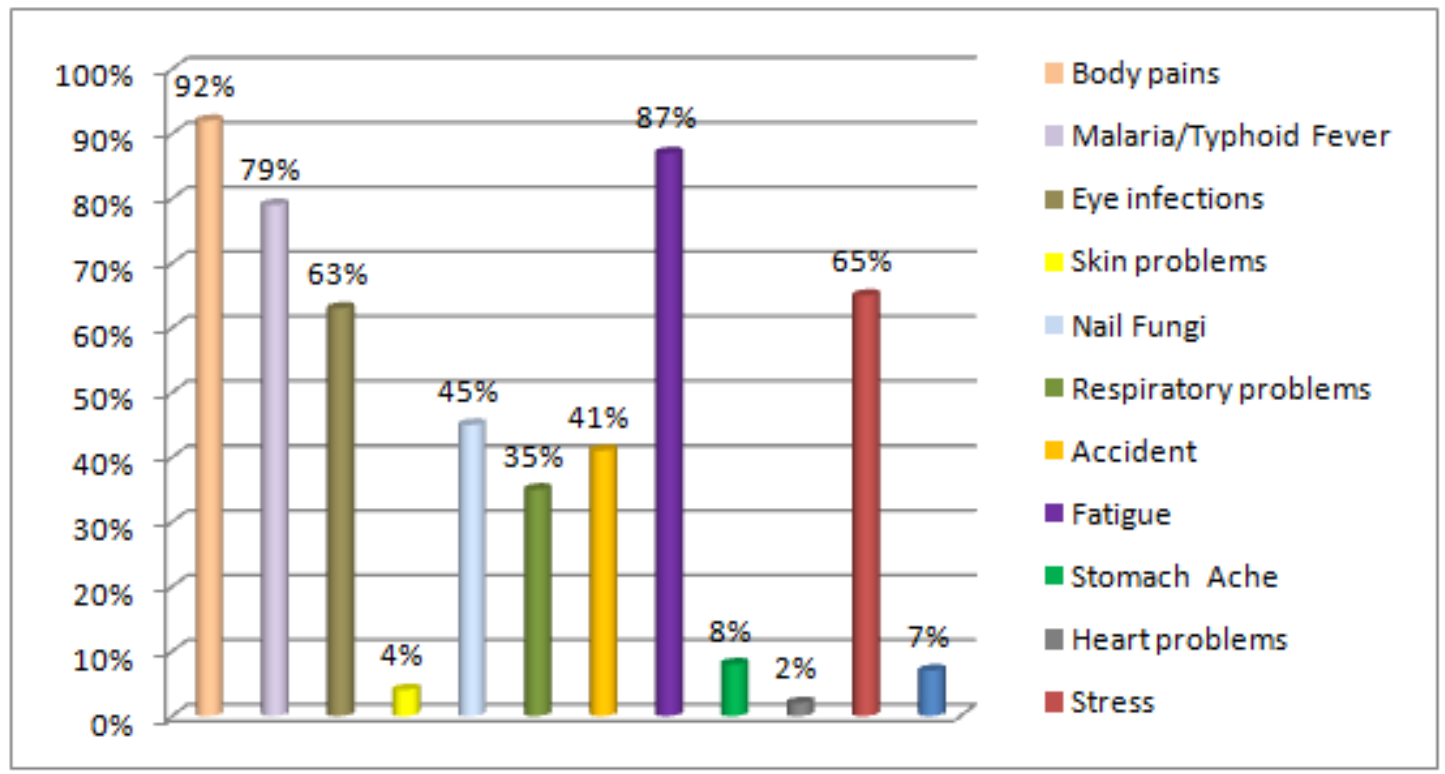

Figure7.2. Health problems of plantation workers

Source: Field survey (2016)

Figure 7.2 showcases different illnesses that affect CDC workers. The most common are body pains $92 \%$, typhoid and malaria $79 \%$ and eye infections $63 \%$.Such is the case with workers in the banana and rubber sectors, since they work for more than 10 hours with their hands in contact with water without gloves.

\subsection{Transportation}

The CDC has a logistic department headed by a logistic manager saddled with the responsibility to provide transportation facilities to all plantation workers living in the camps. About $90 \%$ of the workers interviewed responded that they make use of the company vehicles to reach and leave the plantations. This is why problems such as overcrowded vehicles or breakdown of vehicles affect so many workers (see Photo 7.1).More than $70 \%$ of the workers who use company transport admitted that they were unable to board on the company vehicle at least once a month. In such a situation, the only alternative is to take a taxi or motorbike, the cost of which can vary from 300 to 500 XAF. In addition, they have been several road accidents involving CDC trucks on the Tiko-Douala high way due to overload and over speeding. The government blames most of these accidents on human errors citing careless driving, intoxication and over speeding. They were several corpses littered along the Tiko-Douala road as a result of this accident.

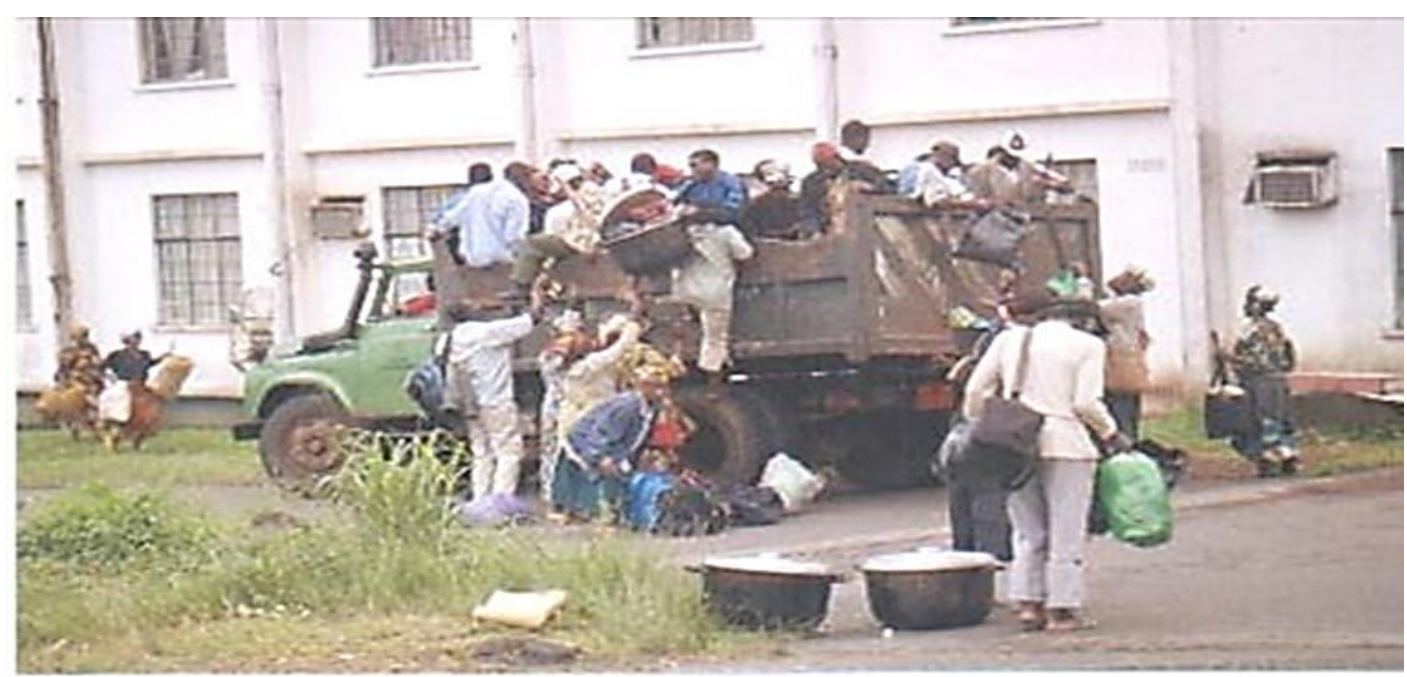

Photo7.1. An overcrowded CTE truck transporting workers

Source: Post News Line (2006) 
Restructuring of the Cameroon Development Corporation, Challenges and Coping Strategies of Plantation Workers in Fako Division, South West Region, Cameroon

Photo 7.1 illustrates protesting Tole tea workers boarding a CTE truck in Bota-Limbeon August 07, 2006 , after a strike action at the CDC headquarters.

\section{Coping Mechanisms of Plantation Workers}

Chambers and Conway (1992:41) assert that for households to ensure a sustainable livelihood they must have access to the five forms of capital assets which are: natural, physical, social, human and financial assets. In Cameroon particularly in the South West Region, access to the five forms of capital assets is difficult owing to environmental challenges and the lack of favourable institutional policies. Livelihood (coping) strategies are a combination of activities and choices that households employ in order to survive (see Table 8.1). They are not only activities that generate income, but also other kinds of choices such as cultural and social that converge to form the primary occupation of a household. These strategic options are short term considerations of earning a living, coping with shocks and managing risk. Households are forced to adopt coping strategies in response to livelihood crises, but the system slowly recovers and households employ a new adapting strategy. Livelihood strategies are positive when they enable households to become resilient and negative when it results to a decrease of the asset base (Ellis 1998). Research the meson livelihood and coping strategies has become the centre of debate in development circles in recent decades and has attracted much attention in development discourse with emphasis more on practice than rhetoric's.

Table8.1. Household coping strategies in CDC camps

\begin{tabular}{|l|l|l|}
\hline Coping Strategies & No. of Respondents & \% \\
\hline Reducing expenditure on food & 120 & 100 \\
\hline On-farm activities/casual labour & 80 & 66.6 \\
\hline Loan/debt & 70 & 58.3 \\
\hline Hair dressing & 08 & 06 \\
\hline Electronic repairer & 06 & 05 \\
\hline Fishing & 08 & 6.6 \\
\hline Hunting & 08 & 6.6 \\
\hline Fuel wood/charcoal & 30 & 25 \\
\hline Petty trading & 40 & 33.3 \\
\hline Selling assets & 10 & 8.33 \\
\hline Skip meal & 30 & 25 \\
\hline Harvesting fruits \& vegetables from thewild & 20 & 16.6 \\
\hline Collecting snails from the forest & 20 & 16.6 \\
\hline Shoe mending & 08 & 6.6 \\
\hline Animal husbandry & 120 & 100 \\
\hline Remittances & 14 & 11.6 \\
\hline Begging & 14 & 11.6 \\
\hline
\end{tabular}

Source: Field survey (2016)

Table 8.1 shows household coping strategies in CDC camps.

NB. Percentage does not add to hundred as households report multiple coping strategies. Their ranking is an indication of household preferences depending on their assets, social and human capital.

This study asserts that $90 \%$ of workers interviewed agreed they took appropriate measures to reduce expenditure on food due to the negative effects of the restructuring of the CDC that led to a drastic cut in their real wages and other fringe benefits provided by the corporation. They employed several coping strategies such as: a change in diet, reduction in the quantity of food during a meal, passed a day without meal or sent out members of the family to eat with their relatives or neighbours. The study also reveal that due to their meagre wages the crises came at a time when most of the workers had very little as savings to fall back on for precautionary motives, in that vein their first coping strategies normally was to reduce expenditure on some non-essential materials.

Furthermore, the collection and sale of fuel wood is a well- documented coping mechanism in most CDC camps. The study reveals that $75 \%$ of households collect fuel wood from the forest or plantation for sale or to be used at home. An assessment of fuel wood supply and demand in the CDC camps reveal that $15 \%$ of households sell fuel wood for income. The wood is collected from secondary forests, CDC rubber and palm plantations. It is a common practice for CDC workers and their 
families to go in search of wood during week end which is considered off-day for most of the workers. In addition, the reliance on remittances from family members is another coping mechanism cited by $15 \%$ of the workers interviewed. Households reported receiving remittances from Europe, Asia and North America. Borrowing from relatives or taking loans with high interest rates are common coping strategies in all the CDC camps surveyed. It is common for people from the same region to always come together in social gatherings to help one another. They have set up "njangi groups" within their tribal gatherings to encourage savings and mutual assistance. It is an informal social security scheme for most poor households in the CDC camps. This social groups give out loans at a low interest rate to members with little guarantee. Plantation workers also reported depositing durable items as guarantees for credit in cash and failure to pay the money, your property is being confiscated by the money lenders.

The study also asserts that CDC households also engage in petty trade. Some households own small stores in front of their houses made with makeshift materials such as bamboos and plywood. These stores supply beer, cigarettes, soap, kerosene and palm oilto plantation workers who are not willing to trek for long distances to buy in the local markets. In addition, some of the women are fully established as food crop entrepreneurs with stores in the local markets in Tiko, Limbe and Mondoni, where they buy as whole sales and retail in the markets, popularly known as "buyam-sellam". They make huge profits from these ventures that make it possible for them to keep large families and also pay the school fees for children. The study also affirms that $90 \%$ of plantation workers were engaged in on-farm activities with their families to supplement their meagre income. Their women take it as a routine activity since they are not employed by the corporation. Their husbands and children join her during weekends to boost the labour force and engage in more activities in the farm. Their reasons for engaging in this activity is mainly to provide food for their families, sell the surplus in the market and buy what they cannot produce. The study also found out that about $45 \%$ of households were engaged in poultry rearing and $14 \%$ in vegetable gardening. It should be noted that nearly all the households surveyed reared either a chicken or goat.

\subsection{Determinants of Coping Responses}

Literature review on coping strategies of poor people in rural areas in developing countries clearly shows that female and male headed households engage in informal activities without adequate resources for the purpose of survival (Salah 1985). This study asserts that more than $80 \%$ of female household heads were engaged in low paying petty trade. The determinants of coping responses are: demographic, socioeconomic and institutional factors. According to the findings of this study, one of the major demographic factors that determine the coping strategies of household heads in CDC camps is their marital status. This is consistent with the view of Wabwire (1997) that economic conditions of household heads vary depending on their marital status. The findings of this study indicate that women who receive support from their spouses are better off than those who are widows or not married. In addition, socio-economic factors play significant roles in the choice of livelihood strategies of household heads in the study area. The study asserts that financial capital is a key factor behind the involvement of most wives of CDC plantation workers in petty trading and food crop entrepreneurship. Due to the difficulty involved in gaining access to credit facilities for big businesses, they find petty trading as the only area of work that they could enter with little difficulty (Farrington et al, 1999).Lastly, this study found out that formal and informal institutions play an important role in the choices of the livelihood strategies of households in CDC camps. In addition, informal institutions are indispensable for the survival of poor households in CDC camps. Poor households get information about job opportunities, food and other basic materials from relatives, friends and neighbours that help them cope with shocks. It should be noted that, families, friends and neighbours are the most influential sources of support for households in CDC camps. On the other hand, religious institutions are amongst the formal institutions that provide moral and psychological support for households in CDC camps (Scoones, 1998).

\subsection{Livelihood Outcomes}

Livelihood outcomes are the achievements of livelihood strategies such as more income, reduced vulnerability, improved food security and a more sustainable use of natural resources. One of the most observed livelihood outcome of the coping strategies employed by the workers has been a marked 
increase in their monthly income, despite a low standard of living. In addition, despite a low monthly wage due to pro-rata accorded most workers their coping strategies has permitted $70 \%$ of households interviewed to raise money by engaging in varied off and on-farm activities enabling households to augment their meagre incomes. Their low standards of living are as a result of their large family sizes, low salaries, poor incentives and high cost of living due to their close proximity to large urban centres in the country. The study also asserts that dueto the existing disenabling policies and institutions (such as: low salaries, pro-rata payments, poor incentives, high cost of living and poor social insurance scheme) prevailing in CDC plantations, the coping strategies employed by workers to curb the negative effects of the neoliberal restructuring are bound to be ineffective resulting to negative livelihood outcomes (see Figure 8.1).

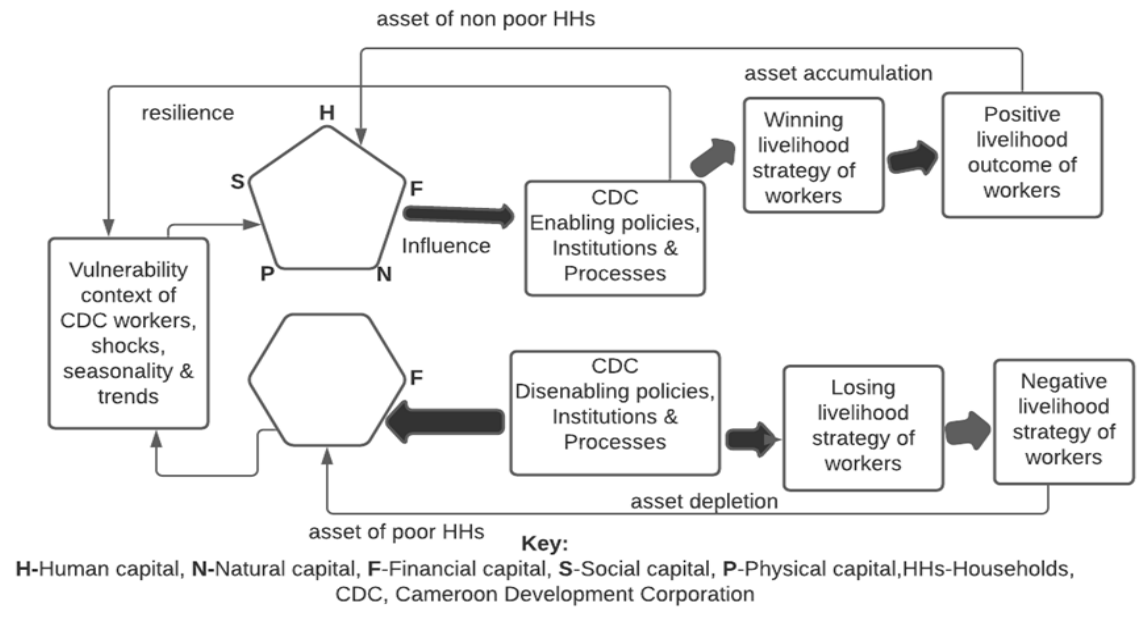

Figure8.1. Livelihood outcome of CDC households

Source: Adapted and modified from Ellis (2000).

Figure 8.1 presents the livelihood outcome of CDC households

The study also asserts that due to the crisis the existing bond of friendship existing amongst plantation workers has been strengthened to a greater extent. The increase number of social groupings in the CDC camps is a living testimony of this assertion. Despite the increase in income for more than $70 \%$ of the workers, less than $6 \%$ own land and other durable assets as a result of their huge debt burden, large family sizes and their engagement in on and off farm activities that generate little income.

\section{DisCUSSION}

The restructuring of the CDC have had very negative consequences on the livelihoods of plantation workers. The privatization negotiations between the CDC and CTE, was done without the consent of CDC workers trade union. In a nutshell the privatization of the CDC was done in closed doors particularly that of the tea sector that has gone done history as the Brobon-Finex saga. The absence of the workers trade union on the negotiating table meant the CDC management did nothing to protect the interest of her workers. In addition, few months after the privatization agreement was signed between the CDC and the CTE, the new management of the CTE decided to carry out massive layoff of unproductive workers from their payroll in order to increase productivity in a bid to make more profits. The CDC also witnessed a huge influx of Francophone managers at the helm of the company which was unusual since they had very little experience on the daily management of plantations and could not express themselves well in the English Language. Their presence led to a drastic drop in output and revenue due to inexperience and the fact that their relation with most of the workers was very poor acting as a disincentive. However, based on the above mentioned arguments, the hypothesis $\left(\mathrm{H}_{\mathrm{a}}\right)$ which states that the restructuring of the CDC have had negative consequences on the livelihood of plantation workers have been validated.

However, the study also shows that one of the most observed livelihood outcome of the coping strategies of workers has been a marked increase in their monthly income, despite the low monthly 
wages paid workers due to pro-rata, their coping strategies has permitted most households to raise money by engaging in different activities, making it possible to augment their meagre incomes. The study also affirms that most households are members of informal saving schemes that help members to raise capital for petty business and to enable the payment of school fees for children. In addition, the low monthly wages makes it difficult for more than $90 \%$ of the workers to educate their children up to high school, provide for themselves and family at least two balanced meals a day. In addition, despite an increase in their monthly income, more than 90\% of CDC workers interviewed acknowledged the fact that due to their large family sizes and huge debt burden, they still live in abject poverty. CDC plantation workers are highly marginalized without a voice in the decision making of the corporation. However, based on the above mentioned arguments and facts presented by this study the hypothesis $\left(\mathrm{H}_{\mathrm{a}}\right)$ which states that the coping strategies employed by plantation workers of the CDC to curb the negative effects of the restructuring on their livelihood have been ineffective has been validated.

\section{CONCLUSION}

The results of the study asserts that plantation workers of the CDC are vulnerable because of the lack of assets, low level of education; lack of better job opportunities elsewhere and low social status in society. Their poor working and living conditions coupled with the meagre wages they collect at the end of the month has drastically reduced them to mere beggars with no hope of a bright future. Despite sacrifices they have been making for the CDC to recover to pre-crisis years, little has been done to compensate them. During the climax of the economic crisis in the mid-1980's plantation workers particularly in Tiko, Mondoni and Tole camps with no alternative job opportunities and assets became very vulnerable and were forced to beg, steal or engage in prostitution in order to provide meals on their table due to long periods without salaries. CDC households with little material, financial, natural and social assets are vulnerable to minor shocks, since they don't have the assets to form the basis of effective coping strategies and resilience that has led to persistent poverty and reduced life expectancy. The coping strategies employed by plantation workers of the CDC to curb the negative effects of the economic crises and the restructuring of the CDC have failed to ameliorate the living and working conditions. There are no signs that the future will be better with the prevailing institutions and policies being implemented by the management of the CDC and CTE geared towards profit maximization at the detriment of the wellbeing of plantation workers. These results might provide useful insights for policy makers on how to alleviate people in rural areas from poverty particularly those of agro-industries with very low minimum wage and poor working conditions. Programmes geared towards alleviating poverty amongst plantation workers should focus on raising the basic minimum wage, protect the rights of workers, empower the CDC workers trade union, increase the amount paid as incentives, reduce the long working hours, ensure safety at work and guarantee a safe retirement.

\section{Conflict of Interests}

The author has not declared any conflict of interests.

\section{ACKNOWLEDGEMENTS}

I am deeply indebted to my supervisor, Professor Moïse Moupou of the University of Yaounde I, whose intellectual guidance and wide research experience ensured completion of this study. In addition, I also wish to extend my gratitude to my Ph.D. colleagues of the University of Yaounde I who assisted me during the data analysis and proof reading of this article.

\section{RESEARCH INTERESTS}

Livelihood and coping strategies, Environmental governance, corporate social responsibility, industrial restructuring, carceral geography, food security, land degradation, land cover change, climate variability and land governance. I work as a civil servant in the Ministry of Secondary Education and also the CEO of CAMPROSUDEV-Cameroon.

\section{REFERENCES}

[1] Konings, P. (1996c): 'Privatisation of agro-industrial parastatal and Anglophone opposition in Cameroon', in: Journal of Commonwealth and Comparative Politics, vol.34, no.3, pp. 199-217.

[2] Konings, P. (1995): 'Plantation labour and economic crisis in Cameroon', in: Development and Change, vol.26, no.3, pp. 525-549. 
Restructuring of the Cameroon Development Corporation, Challenges and Coping Strategies of Plantation Workers in Fako Division, South West Region, Cameroon

[3] Christiansen, Hans. (2013): “Balancing Commercial and Non-Commercial Priorities of State Owned Enterprises. "OECD Corporate Governance Working Paper No. 6. Organization for Economic Cooperation and Development, Paris.

[4] NZOMO, J. T., \& NZONGANG, J. (2007): The process of privatisation of public and Para- public enterprises in Cameroon: An assessment. Journal of sustainable development in Africa, 9(4), 229-246.

[5] WORLD BANK (2018): Research Observer, Volume 33, Issue 1

[6] Skoufias E, Quisumbing AR (2005). Consumption Insurance and Vulnerability to Poverty: A Synthesis of the Evidence from Bangladesh, Ethiopia, Mali, Mexico and Russia. European Journal of Development Research 17: 24-58.

[7] Cameron LA (2001): The Impact of the Indonesian Financial Crisis on Children: An Analysis using the 100 Villages Data. Bulletin of Indonesian Economic Studies 37: 43-64.

[8] National Institute of Statistics (2008a): Third Cameroonian Household Survey (ECAM3). Document of Methodologies, Volume 1. Yaoundé: Republic of Cameroon, Ministry of Economic Affairs, Programming and Regional Development.

[9] Fongod, A. G. N., Veranso, M. C., Libalah, M. (2013): Identification and use of plants in treating infertility in human females in Fako Division, Cameroon, Global J Res. Med. Plants \& Indigen. Med., Volume 2(11): 724-737

[10] Moustakas, C. (1994): Phenomenological research methods. London, Sage

[11] Lofland, J., \& Lofland L. H. (2006): Analysing social settings: a guide to qualitative observation and analysis, Belmont, CA: Wadsworth/Thomson Learning.

[12] Yin, K. R. (2003): “Case Study Research: Design and Methods”, Sage Publications Inc., UK

[13] Konings, P. (1993a): Labour resistance in Cameroon: Managerial strategies and labour resistance in the agro-industrial plantations of the Cameroon Development Corporation, London: James Currey.

[14] Cameroon Development Corporation (2014): Cameroon Development Cooperation. Retrieved 2019, Jan. 08 from http://www.cdc-cameroon.com/.

[15] Post News Line (2006): Angry Workers Ground Work at the Tole Tea Estate. https://www.postnewsline.com/2006/03/angry_workers_g.html. Accessed on the 02/04/2020

[16] Chambers, R. \& Conway G.R. (1992): Sustainable rural livelihoods: practical concepts for the 21st century. Sussex: IDS

[17] Ellis, F. (1998): Household Strategies and Rural Livelihood Diversification. Journal of Development Studies. 35(1): 1-38.

[18] Salah, S. (1985): Peripheral Urbanism and the Sudan: Exploitation in Political Economy of the Wage Labour Market in Greater Khartoum, Unpublished Ph.D. Theses, University of Hull.

[19] Wabwire, A. (1997): Women and Shelter, A study of women headed households in Kampala city -Uganda, Department of Sociology, Makerere University, Kampala, Uganda.

[20] Farrington, J., Carney, D., Ashley, C., \& Turton, C. (1999): Sustainable Livelihoods in Practice: Early Applications of Concepts in Rural Areas. ODI Natural Resource Perspectives, No. 42. London: Overseas Development Institute.

[21] SCOONES, I. (1998): Sustainable Rural Livelihoods: Framework for Analysis. IDS Working Paper 72.

[22] ELLIS, F. (2000): The determinants of rural livelihood diversification in developing countries. Journal of Agricultural Economics, 51(2): 289-302.

\section{AUTHOR'S BIOGRAPHY}

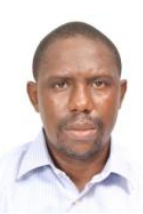

Clovis Ebot Obale, Ph.D candidate, Department of Geography, University of Yaounde I, P.O Box: 812, Yaounde-Cameroon, Faculty of Arts, letters and Social Sciences P.O. Box 755 Yaoundé, Cameroon

Citation: Clovis Ebot Obale. "Restructuring of the Cameroon Development Corporation, Challenges and Coping Strategies of Plantation Workers in Fako Division, South West Region, Cameroon" International Journal of Research in Geography. vol 6, no. 2, 2020, pp. 07-19 doi: http://dx.doi.org/10.20431/24548685.0602002.

Copyright: (C) 2020 Authors. This is an open-access article distributed under the terms of the Creative Commons Attribution License, which permits unrestricted use, distribution, and reproduction in any medium, provided the original author and source are credited. 